\title{
HOPE AND DEPRESSION
}

\section{Book Title:}

Towards the light: Hope in the face of depression

\section{Book Cover:}

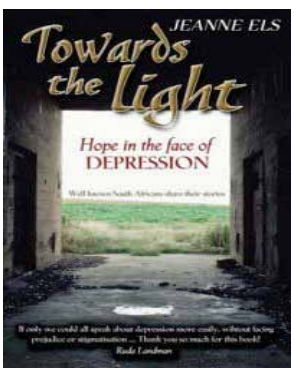

Author:

Jeanne Els

\section{ISBN:}

978-0-7963-0742-2

\section{Publisher:}

Lux Verbi BM, Cape Town, 2008, pp. 224, ZAR79.96* ${ }^{*}$ Book price at time of Review

\section{Review Title:}

Hope and depression

\section{Reviewer:}

Gerhard Bothma ${ }^{1}$

\section{Affiliation:}

${ }^{1}$ Department of Practical

Theology, University of Pretoria, South Africa

email:

gerliese@mweb.co.za

\section{Postal address:}

Department of Practical Theology, University of Pretoria, Lynwood Road, Hatfield 0083, South Africa

How to cite this book review: Bothma, G., 2010,

'Hope and depression', HTS Teologiese Studies/ Theological Studies 66(1), Art. \#987, 1 page. DOI: 10.4102/hts.v66i1.987

\section{This review is available} at:

http://www.hts.org.za
In this book Jeanne Els puts her skills as freelance journalist to good use in which she tells her story of her struggle with depression, whilst simultaneously imparting valuable information on the nature and impact of this often misunderstood illness. It is well written and presented from cover to end. The picture on the cover, which invites the potential reader to step out of the darkness of a cold, unpleasant structure into the light and a landscape in bloom, does not fail the reader. The book provides information and insights that will help break down the stigmas attached to this silent illness in a de-light-ful way.

Apart from her own struggle Els also relates (in a responsible and very sympathetic way) similar stories of a number of well-known South Africans. The way in which they verbalise their own paths with depression will not only help the non-sufferer to develop a sensitivity towards people who are living with depression, but will also dispel many of the myths surrounding an illness not many people are prepared to freely talk about. These candid personal accounts bring the many different faces of depression to light, as well as the wide variety of ways for dealing with it. The book should empower more people to come to terms with depression.

In addition to personal accounts, advice from professionals (such as a medical doctor, a clinical psychologist and a psychiatrist) is also included, together with a glossary of terminology relating to depression and the treatment thereof. A list of books recommended by some of the people, whose stories are told in the book, is also included. Furthermore, useful telephone numbers and internet websites are provided.

Towards the light is worthwhile reading and is recommended. It is also available in Afrikaans as Ligdans: Depressie-vegters se verhale van hoop.
(C) 2010. The Authors. Licensee: OpenJournals Publishing. This work is licensed under the Creative Commons Attribution License. 